\title{
The Plasticity of Students' Language Learning Beliefs: The Interplay of Gender, Grade and Educational Level
}

\author{
Vildana Dubravac \\ International Burch University
}

\begin{abstract}
Correspondence concerning this article should be addressed to Vildana Dubravac, International Burch University, Francuske Revolucije bb, Sarajevo, Bosnia and Herzegovina. E-mail: vildana.dubravac@ibu. edu.ba
\end{abstract}

\author{
Esma Latić \\ International Burch University
}

\begin{abstract}
Correspondence concerning this article should be addressed to Esma Latić, International Burch University, Francuske Revolucije bb, Sarajevo, Bosnia and Herzegovina. E-mail: esmalatic@gmail.com
\end{abstract}

\begin{abstract}
Understanding learners' epistemological beliefs as one of the core segments affecting students' learning experiences is of cardinal importance both from the point of conveying new knowledge and acquiring it. In English language teaching, studying language learning beliefs has become a popular research area, with its genesis found in the seminal paper by Horwitz (1987), whose instrument (BALLI) was employed to collect the data in the present paper. In the underresearched context of Bosnia and Herzegovina, the current study explores the language learning beliefs of 233 elementary school and university students, taking into account the main and interaction effect of three factors: gender, grades, and educational level. Through ANOVA and MANOVA statistical analyses, the results revealed an insignificant main effect of gender and grades on the BALLI while the latter significantly affected one of the area of beliefs assessed by the test. Conversely, educational level demonstrated a significant main effect on both the BALLI and one area. Most importantly, the study showed interesting interplay among the three factors on the shaping of learners' stances. These findings bring significant realization into the complexity of students' beliefs as well as their ever-changing nature with relevant pedagogical implications for the field of second language acquisition.
\end{abstract}

Keywords: BALLI, beliefs, language learning, gender, grade, educational level

\section{Introduction}

In the era of highly diverse societies and ever-growing interdisciplinarity of human endeavor, education worldwide is facing new challenges, one of them being the challenge of effective and appropriate addressing of individual learners' needs (Okogbaa, 2017; York, 2014) shaped by their individual traits as well as current reality, which emerges as a necessary asset in modern education. In the field of Second Language Acquisition (SLA), this state of affairs has been taken into consideration for decades now, and the area has been significantly influenced and molded by this idea of having learners, rather than teachers, as the omphalos of discussion about language teaching and learning (Benson \& Nunan, 2004). Under that realm of individuality, i.e. of both innate and acquired characteristics, including personality type (Dewaele \& Furnham, 2000; Ehrman, 1990; Moody, 1988; Verhoeven \& Vermeer, 2002), foreign language anxiety (Horwitz et al., 1986; Gardner \& MacIntyre, 1994), cognitive styles (Chapelle \& Green, 1992; Ehrman \& Leaver, 2003), and learning strategies (Chaudron, 2003; Dörnyei, 2005; Oxford, 1990), one aspect has aroused a notable amount of interest among the experts - learners' belief systems (Csizer \& Lukacs, 2010; Dörnyei, 2005; Dörnyei \& Ushioda, 2009; Ellis, 1994; Ellis \& Tanaka, 2003; Fillmore et al., 1979; Gardner \& MacIntyre, 1992, 1993; Kalaja \& Barcelos, 2003; Mercer, 2011; Naiman et al., 1978; Zhong, 2012a, 2014). 
Beliefs, here understood as "psychologically held understandings, premises, or propositions about the world that are felt to be true" (Richardson, 1996, p.103), or, in their more specific, language-related variation, learners' attitudes and conceptions about a second or foreign language (L2) learning process (Kalaja \& Barcelos, 2003), underlie and directly as well as indirectly influence and shape L2 acquisition (Ellis, 1994; Gardner et al., 1999; Gardner \& MacIntyre, 1992, 1993; Horwitz, 1999). In fact, according to Ellis (1994), interrelated with learning strategies and final outcomes of learning, these beliefs form a fundament upon which learners actualize their learning processes and mechanisms. Furthermore, it has been indicated that language learning beliefs propel language learning (Abdolahzadeh \& Nia, 2014; Ghavamnia et al., 2011; Ren \& Bai, 2016), lay the ground for conscious development of learning strategies (Azar \& Saeidi, 2013; Ghavamnia et al., 2011), and lower the level of language anxiety (Abraham \& Vann, 1987; Horwitz et al., 1986; Horwitz, 1988). A straightforward corollary of that appears to be that exploring and understanding language learning beliefs seems crucial for the creation and implementation of appropriate L2 curricula and micro-practices of L2 teachers and learners (Castellotti \& Moore, 2002; Horwitz, 1999; Wenden, 1999).

Regardless of the straightforwardness of this analogy, however, the research corpus still seems inconclusive as to the manner and extent of the influence of these beliefs on learning, and their potential interaction with other elements of learners' individuality. Considering the abstraction and elusiveness of beliefs as psychological constructs, it becomes difficult to determine whether they alone lead to (un)successful L2 learning experiences. Therefore, this paper aims to explore the stratification of these beliefs in combination with other factors, in this particular case, gender, grades, and educational level. With that analysis, this study aims to provide clearer insights into the phenomenon and, consequently, less ambiguous implications for pedagogical practices.

\section{Literature Review}

Epistemological beliefs, i.e. beliefs or, broadly speaking, myths about the nature of knowledge and its acquisition, seem to be inherent to human beings, from Socrates and Piaget, to an EFL student in Bosnia and Herzegovina. In other words, an instance of knowledge acquisition is embedded in a set of personal insights (Omaggio, 1978) or implicit theories (Clark, 1988) about learning that not only shape the process of knowledge acquisition, but also, according to Thomas and Harri-Augustein (1983), reveal more about the abilities and performances of individual learners than may be explained through general learning theories. Studying them as forming components of metacognition (Flavell, 1987; Ryan, 1984), psychologists have found epistemological beliefs to extensively influence academic performance (Schoenfeld, 1985), information interpretation (Schommer, 1990; 1993), and persistence in learning (Dweck \& Leggett, 1988). The need to understand the influence of such beliefs on learning outcomes has also been recognized by researchers on language acquisition (Benson, 2001; Oxford, 1992; Wenden, 2001), where Benson and Lor (1999) categorize them based on their methodological approach into the studies taking the normative approach (e.g. Horwitz, 1988; Kern, 1995; Kim-Yoon, 2000; Mantle-Bromley, 1995; Yang, 1992), the metacognitive approach (e.g. Goh, 1997; White, 1999, 1999a; Wenden, 1986a, 1986b, 1998, 1999), and the contextual approach (e.g. Benson \& Lor, 1999; White, 1999). In the first category, Horwitz (1987) protrudes as one of the most significant researchers on this particular issue. Aware of the phenomenon of humans being bound to preconceiving beliefs and expectations before engaging in any learning experience, and with the aim of raising awareness among teachers and scholars about the diversity of language learning beliefs (LLBs) learners hold and their potential, positive as well as negative, consequences for learning and teaching processes, Horwitz (1987) conducted a study in which she explored the convictions of beginning university foreign language students. For the purposes of the study, the Beliefs About Language Learning Inventory (BALLI) was developed, grounded in common assumptions of L2 teachers and students about language learning, and extracted into five different exploratory categories: (1) foreign language aptitude, (2) difficulty of language learning, (3) nature of language learning, (4) learning and communication strategies, and (5) motivations and expectations. Thereby, she gave an impetus for further investigation, with BALLI-based studies having been conducted across different language groups and sociocultural realities (Ariogul \& Onursal, 2009; Amuzie \& Winke, 2009; Barcelos, 2000; Bernat, 2004, 2006; Bernat \& Gvozdenko, 2005; Diab, 2006; Hong, 2006; Horwitz, 1999; Kim, 2001; Kuntz, 1997; Mercer, 2011; Mori, 1999; Nikitina \& Furuoka, 2007; Oz, 2007; Rieger, 2009; Siebert, 2003; Su, 1995; Tercanlioglu, 2004; Wenden, 1999; Yang, 1999; Zhang \& Cui, 2010).

Reviewing them through the lens of more specific categorization, a number of them investigated the relationship between the beliefs and motivation (Csizér \& Dörnyei, 2005; Ehrman \& Oxford, 1995; Samimy \& Lee, 1997; White, 1999), several explored them in association with language learning strategies (Azar \& Saeidi, 2013; Ghavamnia 
et al., 2011), and yet others explored the correlation between LLBs and language proficiency (Abdolahzadeh \& Nia, 2014; Fujiwara, 2014; Ghavamnia et al., 2011; Hong, 2006; Kunt, 1997; Mori, 1999; Park, 1995; Peacock, 1999; Samimy \& Lee, 1997; Zhong, 2012a). The latest category perhaps most clearly illustrates the possible impact of LLBs on language learning, where a significant number of studies have shown a positive relationship between the constructs. There, exploring the correlation between the beliefs of 332 Korean university students and their English proficiency as reflected in their TOEFL scores, Park (1995) revealed that LLBs, alongside the use of learning strategies, positively predicted their success. More specifically, EFL learning confidence, the willingness to communicate in English, and the tendency to observe one's own progress, seemed to support their L2 acquisition, as was also found in Samimy and Lee's (1997) study of Chinese learners of EFL. In the same trend, Fujiwara (2014) found a positive correlation among Thai EFL university students, where more proficient ones were significantly more convinced that English is an easy language to learn, that their country's people and also themselves are good at learning foreign languages, and that their own learning outcomes are likely to be successful. They also demonstrated weak beliefs in the importance of grammar, translation, memorization, and 'perfect' language accuracy. A similar tendency of understanding the complexity of language learning process was found among Mori's (1999) participants, where, once again, LLBs were positively correlated with English proficiency, now of Japanese learners. Thus, the research corpus seems to indicate that more proficient L2 learners are likely to hold positive beliefs about their innate abilities as well as the potential outcomes of their learning, naturally implying higher confidence levels and potentially resulting in more open and frequent language use.

While the previous research observed language learning beliefs as part of the network of causal factors in the process of L2 learning, some other studies investigated them as molded by different factors, such as learners' culture (Horwitz, 1999; Lee, 2014; Mori, 1999; Poza, 2013; White, 1999), age (Fujiwara, 2014; Lee, 2014), type of L2 (Ariogul et al., 2009; Horwitz, 1988; Meshkat \& Saeb, 2014), and gender (Bernat \& Lloyd, 2007; Lee, 2014; Siebert, 2003; Tercanioglu, 2005). In terms of differences between females and males, Siebert (2003), carried out a study among 156 (64 female and 91 male) university students learning English in the United States, and found statistically significant differences in certain conceptions; e.g. male students were more likely than their female counterparts to highly rate their own language learning abilities as well as those of their country's people's, to estimate the learning time as shorter, to rate grammar as the most important part of language learning, etc. On the other hand, Siebert (2003), Bacon and Finnemann (1992) and Kunt (1997), all found that females expressed a stronger desire to interact with the target language culture and its speakers. These studies' findings were later questioned by research in which no statistically significant gender effect on LLBs was found (Bernart \& Lloyd, 2007; Fujiwara, 2014; Lee, 2014; Tercanioglu, 2005). In the interpretation of their findings, Tercanlioglu (2005) suggested that the lack of differences might be an indicator of the need to understand the impact of these individual differences only in the context of other personal variables, such as age, stage of life, and cultural particularities.

Age, as one of these key variables, has also been a focal point of some LLB-based studies. There, Fujiwara (2014) explored whether there are any significant differences between three age groups of university-level participants, and found that age did not play an important role in the existence or strength of LLBs. Furthermore, Lee (2014) studied four different age groups, and also revealed that the effect of age on LLBs was not statistically significant. Khodadady (2009), on the other hand, discovered that, among his university-level students ranging from the age of 19 to 49 , there was a statistically significant difference between sophomore undergraduate students and senior undergraduate as well as graduate students in eleven beliefs based on the BALLI. In relation to the effect of age or, more broadly, time, it is important to note certain studies in which language learning beliefs were considered to be in a constant state of flux, and were thus observed through longitudinal research. One of them was Elis and Tanaka's (2003) research, in which Japanese learners in a fifteen-week-long study abroad program significantly changed their beliefs, particularly relating to self-efficacy and confidence. In a similar fashion, Mercer's (2011) three-year-long study concluded that beliefs are dynamic constructs prone to change differing in character and frequency; some beliefs changed in terms of their content, other changed in terms of their strength, and certain convictions were almost immune to change. Zhong (2015) confirmed these findings, inferring that LLBs are modified over time under the influence of different contextual factors, such as changes in teaching approaches as well as the natural progression of a course.

These findings, being evidently and reasonably inconclusive in their entirety, point to the complexity of the phenomenon of LLBs and their relation with language learning. However, not many studies have focused 
on simultaneous interactions of individual differences in the creation of LLBs, which is arguably crucial for elucidating the complexity and sensitiveness of any such construct (Gardner et al., 1997). Therefore, this study aims to provide a more detailed analysis by taking into consideration three different variables that may be determinative in the construction of LLBs; namely, gender, educational level, and grades of students in Bosnia and Herzegovina. Despite different studies related to the process of EFL learning having been conducted in this sociocultural context, such as the studies measuring the impact of diverse factors on students' English language proficiency as well as the proficiency itself (Brdarević-Čeljo et al., 2018; Delić et al., 2018; Habibić \& Dubravac, 2016; Kovačević et al., 2018; Rizvić \& Bećirović, 2017) and their use of learning/reading strategies (Bećirović et al., 2017; Bećirović et al., 2018; Brdarević-Čeljo \& Asotić, 2017; Tankosić \& Dubravac, 2016), studies exploring learners' LLBs are quite rare. Thus, one of the studies explored the state of LLBs among high-school students (Ozturk \& Turkyilmaz, 2014), another one investigating the correlation between the beliefs and language learning strategies (Akbarov \& Kovačević, 2015), and finally, the relationship between LLBs and the complexity of syntactic structures used by language learners (Kovačević, 2017). The study by Ozturk \& Turkyilmaz (2014) showed that Bosnian high-school students tend to hold fairly strong beliefs about foreign language aptitude (M = 3.39), the difficulty of language learning $(\mathrm{M}=3.06)$, the nature of language learning $(\mathrm{M}=3.59)$, learning and communication strategies $(M=3.42)$, as well as motivation and expectations $(M=4.13)$. In their exploration of the relationship between LLBs and language learning strategies among Bosnian university students, Azamat and Kovačević (2015) discovered no statistically significant correlation between the constructs. Finally, Kovačević's (2017) recent study investigated whether LLBs affect the complexity of syntactic structures used by students and arrived at quite an unusual discovery of L2 learners with strong beliefs demonstrating simpler syntactic structures in their writings. Thus, in a country in which EFL teachers are facing issues with developing learners' proficiency regardless of the fact that being able to use English is becoming a sine qua non for an educated individual and where both formal and informal EFL learning opportunities are abundant, it seems crucial to make laborious scientific efforts in order to clarify what constitutes optimal learning conditions and requirements.

Thus, the presented study tested the following hypotheses:

1. There is no significant difference in the participants' beliefs about language learning (BALLI) based on their gender, educational level and average English grade. These factors do not interact in the effect on the learners' beliefs about language learning (BALLI).

2. There is no significant difference in the specific learners' beliefs about language learning, namely foreign language aptitude, the difficulty of language learning, the nature of language learning, learning and communication strategies, and motivation and expectations, based on their gender, age and grade. These factors do not interact in the effect on the aforementioned specific learner beliefs.

\section{Methodology}

\section{Participants}

The sample for the present study comprised 233 participants, all of whom at the time of collecting the data were studying in Bosnia and Herzegovina, 96 of them being male and 137 female. Two target groups were chosen, one of students in elementary education, aged 11-12, and the other of students with an age span between 18 and 25, studying at the university level. The former group of students were, thus, sixth-grade students from a state elementary school in Zenica-Doboj Canton, and the latter were first, second, third, or fourth-year students studying at two universities in Bosnia and Herzegovina, one private in Sarajevo Canton and one state in ZenicaDoboj Canton, in the following faculties: Faculty of Education and Humanities, Faculty of Philosophy, Islamic Pedagogical Faculty, and School of Medicine.

Since the third characteristic by which the participants were compared was their English grades, they were asked to report their average English grade. The elementary school students provided the average grade from the previous three years during which they had been officially taught the English language. The junior students provided their average high school English grade, since at the time of conducting the research they had still not been graded in their English course at the university level, while the other students were asked to provide the grade they obtained in their university English course, with the exception of the English majors who were asked to provide their GPA. While the grade scale in elementary and high school ranged from 1 to 5 , at the university 
level the scale was 5 - 10 . To make the comparison simpler, the university grades were adjusted and thus 5 was coded as 1, $6.00-6.99$ as 2, 7.00-7.99 as 3, $8.00-8.99$ as 4, and $9.00-10.00$ as 5. All relevant details about the participants are displayed in Table 1.

Table 1

Descriptive statistics for the participants

\begin{tabular}{lcc}
\hline Group & $\mathbf{N}$ & Percent \\
\hline Gender & 96 & 41.2 \\
Male & 137 & 58.8 \\
Female & & \\
Educational level & 118 & 50.6 \\
Elementary & 115 & 49.4 \\
University & & \\
Grade & 36 & 15.5 \\
2 & 63 & 27 \\
3 & 65 & 27.9 \\
4 & 69 & 29.6 \\
5 & $\mathbf{2 3 3}$ & $\mathbf{1 0 0}$ \\
\hline total & & \\
\hline
\end{tabular}

\section{The instrument}

The survey instrument for this study was the Beliefs about Language Learning Inventory (BALLI) designed by Horwitz (1987) and used in numerous studies as a reliable and valid instrument. It also proved internally consistent with the present study sample, with the Cronbach's Alpha coefficient being above .70 $(\alpha=.713)$. The survey consists of 34 questions investigating five different areas of beliefs: (1) foreign language aptitude, (2) the difficulty of language learning, (3) the nature of language learning, (4) learning and communication strategies, and (5) motivations and expectations. The questionnaire was designed so that the items are rated on a Likerttype scale ranging from 1 , 'strongly disagree' to 5 , 'strongly agree'.

In addition to the main instrument, a general demographic survey identifying students' age, gender, and grades was used. Since some of the participants had not developed a considerable level of English proficiency, so they were given the survey in their mother tongue to ensure a full understanding of all the statements. Thus, the English majors completed the survey in English, and all the other students in Bosnian.

\section{Procedure}

After gaining consent from the relevant parties, the participants and their parents in the case of elementary school students, the researchers distributed the survey and provided clear and detailed guidelines. The students were informed that the survey was anonymous and were asked to provide accurate answers mirroring their beliefs, which would be used only for the purpose of this research. The surveys were completed at the participants' university/ school premises in the period from February 2017 to October 2018.

\section{Data analysis}

The data were analyzed using SPSS, by the means of which descriptive and inferential statistics were obtained. A factorial ANOVA was used to assess the impact of gender, educational level, and grades on the BALLI, while a factorial MANOVA was performed in order to check the impact of the aforementioned factors on the BALLI's five areas of beliefs. In addition to these comparisons based on the overall instrument and the specific areas of beliefs, the data for individual items were analyzed since this instrument, as suggested by its designer Horwitz (1985), is not an inventory yielding "a composite score“ (p. 334), but individual items providing useful and relevant information pertaining to different domains of learner beliefs. Table 2 presents descriptive statistics for the overall BALLI as well as the areas of beliefs it assesses, namely foreign language aptitude, the difficulty 
of language learning, the nature of language learning, learning and communication strategies, and motivation and expectations As can be seen, the mean scores were in the range from $M=3.21$ for the area of the difficulty of language learning to $M=4.12$ for the motivation and expectations area. The correlation coefficients indicating the relationship between the areas were not particularly high, but rather moderate, and sometimes the correlation was even insignificant, such as between the area of the difficulty of language learning, on the one hand, and the areas of motivation and expectations $(r=109, p>.05)$ and foreign language aptitude $(r=102$, $p>05$ ), on the other. The strongest correlation existed between the area of the nature of language learning and learning and communication strategies $(r=493, \mathrm{p}<.01)$.

Table 2

Descriptive statistics and correlation for the BALLI and its subscales

\begin{tabular}{|c|c|c|c|c|c|c|}
\hline Scale & $\mathbf{M}$ & SD & $\begin{array}{c}\text { difficulty of } \\
\text { language } \\
\text { learning }\end{array}$ & $\begin{array}{c}\text { nature of } \\
\text { language } \\
\text { learning }\end{array}$ & $\begin{array}{c}\text { learning and } \\
\text { communication } \\
\text { strategies }\end{array}$ & $\begin{array}{c}\text { motivation and } \\
\text { expectations }\end{array}$ \\
\hline foreign language aptitude & 3.56 & .45 & 102 & $.335 * *$ & $.404^{* * *}$ & $.489 * *$ \\
\hline difficulty of language learning & 3.21 & .47 & & $.245^{* * *}$ & $.154^{*}$ & .109 \\
\hline nature of language learning & 3.70 & .61 & & & $.493 * *$ & $.351^{* * *}$ \\
\hline $\begin{array}{l}\text { learning and communication } \\
\text { strategies }\end{array}$ & 3.44 & .44 & & & & $.317^{* * *}$ \\
\hline motivation and expectations & 4.12 & .59 & & & & \\
\hline BALLI & 3.60 & .34 & & & & \\
\hline
\end{tabular}

\section{Results}

A three way ANOVA was performed to show the main and interaction effect of gender, educational level, and grades on the BALLI. The results revealed an insignificant main effect of gender $F(1,217)=.989, p=.321, \eta 2$ $=.005$, and grade $F(3,217)=.441, p=.724, \eta 2=.006$. Thus, the male $(M=3.57)$ and female participants' $(M=$ 3.62) beliefs were not significantly different on the BALLI nor were the beliefs of the groups with the average grade $2(M=3.65)$, grade $3(M=3.55), 4(M=3.60)$ and $5(M=3.61)$. However, the effect of educational level on the BALLI proved significant $F(1,217)=4.76, p=.030, \eta 2=.021$, with the mean obtained on the BALLI by the elementary school students $(M=3.66)$ surpassing the mean $(M=3.54)$ the university level students achieved on it. The interaction effect of gender X educational level was significant $F(1,217)=5.536, p=0.20, \eta 2=.025$, with the elementary school female participants' $(M=3.65)$ and male participants' means $(M=3.60)$ being higher than those scored by the university female $(M=3.59)$ and male students $(M=3.57)$. Nevertheless, the interaction effects of gender X grade $(p=.777)$, gender X educational level X grade $(p=.601)$ and educational level X grade $(p=.076)$ were insignificant.

A factorial MANOVA was conducted to check the main and interaction effect of gender, educational level, and grades on the areas of beliefs comprising the BALLI. The main effect of gender - Pillar's Trace $=.044, F(5,213)=$ $1.98, p=.082$, partial eta squared $=.044$, on the overall dependent variables proved to be insignificant, whereas the main effect of educational level - Pillai's Trace $=.069, F(5,213)=3.16, p=.009$. partial eta squared $=.069$, as well as grades - Pillai's Trace $=.123, F(15,645)=1.84, p=.026$, partial eta squared $=.041$ was significant. The interaction effects of grade level X gender $(p=.900)$, grade level X educational level $(p=.053)$, and gender $\mathrm{X}$ educational level X grade level $(p=.881)$ on the combined dependent variables were insignificant, while the interaction effect of gender X educational level - Pillai's Trace $=.058, F(5,213)=2.62, p=.025$, partial eta squared $=.058$ on the combined five aforementioned variables proved to be statistically significant.

When the main and interaction effects were analyzed separately for the areas, the effect of gender on all the areas individually was insignificant, although the mean scores achieved by the male and female participants were slightly different (Table 3). On the area of foreign language aptitude (Table 6), learning and communication strategies (Table 9), and motivation and expectations (Table 10), the scores by the female participants were a 
bit higher, whereas the opposite findings were revealed in the case of the other two areas (Table 7, Table 8). For instance, the female participants agreed more strongly with the statements that they have special ability for learning foreign languages $(M=3.44)$, that everybody can learn a foreign language $(\mathrm{M}=4.06)$, that women are better than men at learning languages $(M=2.87)$, that it is important to repeat and practice a lot $(M=$ 4.55), that they feel shy speaking English to other people $(M=2.43)$, and that they would like to have English speaking friends $(\mathrm{M}=4.30)$. On the other hand, the greater majority of the male participants accepted as true the statements that it is easier to speak than to understand a foreign language $(M=2.97)$, that it is best to learn English in an English speaking country $(M=4.15)$, and that in the process of language learning words are the most important $(M=4.07)$.

Educational level was shown to have a significant effect on the area of the nature of language learning $F(1,217)$ $=7.485, \mathrm{p}=.007, \eta 2=.014$ (Table 4), with the elementary school students expressing a stronger agreement with the statement that it is necessary to learn about English speaking cultures to speak English $(M=3.50)$, while also claiming a stronger belief in the importance of learning new words $(M=4.28)$, grammar $(M=3.95)$, and translation $(M=3.75)$. Conversely, the university students believed more in learning English in the target speaking country $(M=4.31)$ and the specificity of learning a foreign language in comparison to learning other subjects $(M=4.17)$ (Table 8$)$.

The effect of grades was significant only on the area of motivation and expectations $F(3,217)=2.875, p=.037$, $\eta 2=.038$ (Table 5), with the mean scores mainly rising in accordance with the grades, thus the better the grades, the more optimistic the learners were about their English proficiency development. Further comparisons among the students with different grades revealed that the better the grades were, the less shy the students were while speaking English, the less they believed that one should not say anything in English unless it can be said correctly, the less they believed that grammar is the most important aspect to be learned, and that it is easier to read and write than to speak and understand English, but the more they believed that English is an easy language to acquire (Table 10).

Table 3

Multivariate ANOVA between the male and female students on the subscales of the BALLI

\begin{tabular}{|c|c|c|c|c|c|c|}
\hline \multirow{3}{*}{ Scale } & \multicolumn{4}{|c|}{ Gender } & \multirow{3}{*}{$\mathbf{p}$} & \multirow{3}{*}{$\eta 2$} \\
\hline & \multicolumn{2}{|c|}{ Male } & \multicolumn{2}{|c|}{ Female } & & \\
\hline & $\mathbf{M}$ & SD & $\mathbf{M}$ & SD & & \\
\hline Foreign language aptitude & 3.48 & .49 & 3.62 & .41 & .077 & .014 \\
\hline Language learning difficulty & 3.27 & .46 & 3.16 & .48 & .065 & .016 \\
\hline Nature of language learning & 3.71 & .65 & 3.69 & .59 & .943 & .000 \\
\hline Learning and communication strategies & 3.40 & .49 & 3.47 & .40 & .284 & .005 \\
\hline Motivation and expectations & 4.06 & .60 & 4.16 & .58 & .388 & .003 \\
\hline
\end{tabular}

Table 4

Multivariate ANOVA between the elementary and university students on the subscales of the BALLI

\begin{tabular}{|c|c|c|c|c|c|c|}
\hline \multirow{3}{*}{ Scale } & \multicolumn{4}{|c|}{ Educational level } & \multirow{3}{*}{$\mathbf{p}$} & \multirow{3}{*}{$\eta 2$} \\
\hline & \multicolumn{2}{|c|}{ Elementary } & \multicolumn{2}{|c|}{ University } & & \\
\hline & $\mathbf{M}$ & SD & $\mathbf{M}$ & SD & & \\
\hline Foreign language aptitude & 3.54 & .47 & 3.58 & .42 & .557 & .002 \\
\hline Language learning difficulty & 3.34 & .51 & 3.08 & .40 & .236 & .075 \\
\hline Nature of language learning & 3.83 & .63 & 3.57 & .57 & .007 & .033 \\
\hline Learning and communication strategies & 3.50 & .47 & 3.38 & .39 & .077 & .014 \\
\hline Motivation and expectations & 4.19 & .62 & 4.04 & .55 & .053 & .017 \\
\hline
\end{tabular}


Table 5

Multivariate ANOVA between students with grades 2, 3, 4 and 5 on the subscales of the BALLI

\begin{tabular}{|c|c|c|c|c|c|c|c|c|c|c|}
\hline \multirow{3}{*}{ Scale } & \multicolumn{8}{|c|}{ Grade } & \multirow{3}{*}{$\mathbf{P}$} & \multirow{3}{*}{$\eta 2$} \\
\hline & \multicolumn{2}{|c|}{2} & \multicolumn{2}{|c|}{3} & \multicolumn{2}{|c|}{4} & \multicolumn{2}{|c|}{5} & & \\
\hline & $\mathbf{M}$ & SD & $\mathbf{M}$ & SD & $\mathbf{M}$ & SD & M & SD & & \\
\hline Foreign language aptitude & 3.51 & .38 & 3.48 & .47 & 3.64 & .39 & 3.59 & .49 & .225 & .020 \\
\hline Language learning difficulty & 3.42 & .46 & 3.23 & .49 & 3.12 & .45 & 3.17 & .45 & .489 & .011 \\
\hline Nature of language learning & 3.92 & .71 & 3.71 & .63 & 3.65 & .54 & 3.63 & .60 & .077 & .031 \\
\hline Learning and communication strategies & 3.55 & .41 & 3.43 & .49 & 3.42 & .41 & 3.41 & .44 & .551 & .010 \\
\hline Motivation and expectations & 3.87 & .62 & 3.96 & .64 & 4.19 & .53 & 4.31 & .50 & .037 & .038 \\
\hline
\end{tabular}

The interaction of grade level X gender was insignificant in the effect on foreign language aptitude $(p=.929)$, language learning difficulty $(p=.854)$, the nature of language learning $(p=.448)$, learning strategy and communication $(p=.748)$, and motivation and expectations $(p=.598)$. The same results were obtained in the case of the interaction effect of grade level $\mathrm{X}$ gender $\mathrm{X}$ educational level, with all the $\mathrm{p}$ values being higher than .05 . However, the independent variables grade level $\mathrm{X}$ educational level significantly interacted in the effect on the nature of language learning $F(3,233)=3.18, p=.025, \eta 2=.042$, while the effect of these variables was insignificant on the foreign language aptitude $(p=.717)$, the difficulty of language learning $(p=.141)$, learning and communication strategies $(p=.072)$, and motivation and expectations $(p=.221)$. Regarding the area of the nature of language learning, the scores of the elementary school students were generally higher than those of the university students with the exception of the students with grade level 2 , where the university level students obtained a higher mean score $(M=4.09)$ in comparison to the elementary school students with the same grade level $(M=3.82)$. However, while the university students' mean scores were lower, as the grades increased from $M=4.09$ for the students with grade level 2 to $M=3.40$ for the students with grade level 5 , the situation with elementary school students was not the same, the means having the following values: grade level $2(M=3.82)$, grade level $3(M=3.93)$, grade level $4(M=3.84)$ and grade level $5(M=3.77)$. (Figure 1$)$.

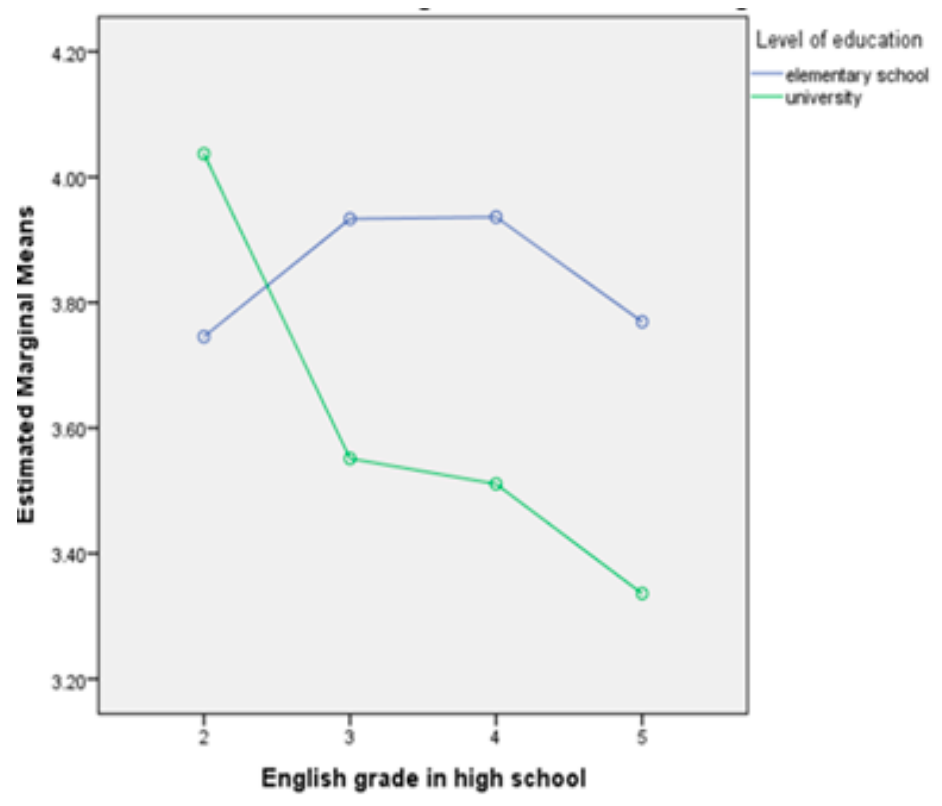

Figure 1. Differences between elementary school and university students across different grade groups on the subscale of the nature of language learning.

The analysis of the differences in the scores obtained for specific items constituting this area indicated that the elementary school students $(M=3.52)$ expressed a stronger belief in the necessity of knowing about the native culture in order to speak the target language than the university students $(M=2.84)$, although that increase in the grades was followed by decrease in the level of conviction, the means in the group of the elementary school 
students ranging from $(M=4.00)$ to $(M=3.37)$, and from $(M=3.57)$ to $(M=2.56)$ among the university students. This was not the case with the statement that it is best to learn English in an English-speaking country, with the university students accepting it more readily as correct $(M=4.30)$ than the elementary school students $(M=3.84)$. Interestingly, while the scores were higher as the grades were lower in the former, from $(M=4.71)$ in the groups of the university students with grade level 2 to $(M=4.08)$ among the students with grade level 5 , the opposite was noticed for the latter, the scores being in the range from $(M=3.77)$ among the students with grade level 2 to $(M=3.91)$ among those with grade level 5 . Generally, the students at both the elementary $(\mathrm{M}=4.28)$ and university level $(M=3.77)$ assigned more importance to vocabulary than grammar, with the mean scores for the statement related to the importance of grammar in the process of language learning being $(\mathrm{M}=3.95)$ among the elementary and $(M=3.19)$ among the university students. However, while the elementary school students regardless of their grades expressed a strong belief in the importance of learning grammar, the scores among university students became lower as the grades were higher. Thus, the mean score in the university students group at grade level $2(M=3.36)$ fell to $(M=2.80)$ in the group of their peers at grade level 5 . The variations among the students with different grades were not great in the case of the statement pertaining to the importance of translation, even though a stronger agreement with this statement was noticed among the elementary school students $(M=3.76)$ than among the university students $(M=3.17)$.

Gender X educational level proved to significantly interact in the effect on the three areas of beliefs, namely the nature of language learning $F(1,217)=6.96, \mathrm{p}=.009, \eta 2=.031$, motivation and expectations $F(1,217)=4.231$, $p=.041, \eta 2=.019$, and learning and communication strategies $F(1,217)=7.627, p=.006, \eta 2=.034$, while the effect of the variables was insignificant on the area of foreign language aptitude $(p=.601)$ and the difficulty of language learning $(p=.580)$. When it comes to the nature of language learning, both the male and female students in elementary school $(M=3.52)$ believed in the importance of being familiar with the native culture more than the university students $(M=2.84)$, with the male students in both groups accepting the statement as correct a bit more readily. However, both the elementary $(M=3.84)$ and university students $(M=4.30)$ gave more importance to learning English in the target country, without significant variations between the male and female students. Interestingly, while the male elementary school students $(M=4.38)$ believed in the importance of learning new words more than the female students from the same group $(M=4.20)$, the opposite was noticed for the university students, with $(M=3.82)$ scored by the female students and $(M=3.68)$ by the male students. Furthermore, the male participants in elementary school $(M=3.81)$ believed more than the females $(M=3.51)$ that learning a language is different from learning other subjects, whereas the opposite was noticed for the female university students $(M=4.29)$ in comparison to the male students $(M=3.83)$. The greatest difference was observed in the case of the statement related to translation with the following means achieved by the female $(M=3.67)$ and male $(M=3.87)$ students in elementary school, and $(M=3.28)$ for the female and $(M=2.98)$ for the male university students.

Regarding the comparison between these groups on the area of motivation and expectations, the greatest differences were noticed for the beliefs pertaining to the statement that people in our country consider speaking English important. The mean obtained by the elementary school female students $(M=3.73)$ was slightly higher than the elementary school male students' mean $(M=3.67)$, but a much greater distinction was noticed among the university students, with the female students' mean $(M=3.89)$ greatly surpassing the one obtained by the male students (v3.27). The relation between the scores was also surprising in terms of items 22, 27, and 29. While the male students' means ( $M=4.41$ for item 22 and item 27 , and $M=4.61$ for item 29 ) were higher than the female students' ( $M=4.10$ for item $22, M=4.37$ for item 27 , and $M=4.50$ for item 29) in the group of the elementary school students, the opposite was found among the other group of the participants, with the means achieved by the female participants ( $M=3.45$ for item $22, M=4.40$ for item 27 , and $M=4.58$ ) being higher than the ones obtained by the male university students $(M=3.12$ for item 22 , v4.12 for item 27 , and $M=4.46$ for item 29).

Finally, as for the items constituting the area of learning and communication strategies, the male elementary school students $(M=2.54)$ felt more shy when speaking English with other people than the female students $(M=2.10)$, whereas the converse appears to be true in the group of the university students, with the mean achieved by the female students $(M=2.71)$ being much higher than the mean of the male students $(M=2.15)$. Moreover, while the elementary school students generally believed more strongly that excellent pronunciation presented a prerequisite for speaking English, the statement was more supported among the male elementary school students $(M=3.90)$ than among the female students $(M=3.83)$, while among the university students, 
the female students $(M=3.42)$ expressed a stronger belief in this claim than the male students from the group $(M=3.20)$. The same was observed for the belief that it is OK to guess if one does not know the right word in English, as the male students $(M=3.78)$ in elementary school believed in this more firmly than the female students $(M=3.61)$, whereas the female university students $(M=3.76)$ agreed with the claim more readily than their male counterparts $(M=3.56)$. Similar findings were reported for item 20 , i.e. the statement claiming that error correction in the initial stages of language learning is important for subsequent correct speaking in English. Thus, while more male $(\mathrm{M}=3.98)$ than female $(M=3.66)$ elementary school students supported this belief, the mean among the female university students $(M=3.65)$ was higher than the mean among the male university students $(M=2.98)$. On the contrary, the female elementary school students seemed to enjoy practicing English with native speakers more than their male peers $(M=3.72)$, while the male university students $(M=4.05)$ were more likely to do so than the female students $(M=3.92)$.

Table 6

Multivariate ANOVA between different groups of the participants on the subscale of foreign language aptitude

\begin{tabular}{|c|c|c|c|c|c|c|c|c|c|c|c|c|c|c|c|}
\hline \multirow[b]{2}{*}{ Item } & \multirow[t]{2}{*}{ Total } & \multicolumn{2}{|c|}{ Gender } & \multirow[b]{2}{*}{$\mathbf{p}$} & \multirow[b]{2}{*}{$\eta 2$} & \multicolumn{2}{|c|}{ Educational evel } & \multirow[b]{2}{*}{$\mathbf{p}$} & \multirow[b]{2}{*}{$\eta 2$} & \multicolumn{4}{|c|}{ Grade } & \multirow[b]{2}{*}{$\mathbf{p}$} & \multirow[b]{2}{*}{$\eta 2$} \\
\hline & & Male & Female & & & $\begin{array}{c}\text { Eleme- } \\
\text { ntary }\end{array}$ & $\begin{array}{c}\text { Univer- } \\
\text { sity }\end{array}$ & & & 2 & 3 & 4 & 5 & & \\
\hline Item 1 & 4.28 & 4.27 & 4.28 & .719 & .001 & 4.10 & 4.46 & .002 & .046 & 4.28 & 4.22 & 4.26 & 4.34 & .684 & .007 \\
\hline Item 2 & 4.24 & 4.05 & 4.37 & .078 & .015 & 4.18 & 4.30 & .499 & .002 & 4.44 & 4.08 & 4.35 & 4.16 & .290 & .018 \\
\hline Item 5 & 3.28 & 3.22 & 3.32 & .871 & .000 & 3.14 & 3.42 & .121 & .012 & 3.09 & 3.35 & 3.44 & 3.16 & .021 & .046 \\
\hline Item 9 & 3.47 & 3.51 & 3.43 & .888 & .000 & 3.42 & 3.51 & .696 & .001 & 3.50 & 3.41 & 3.44 & 3.51 & .990 & .001 \\
\hline Item 10 & 2.68 & 2.69 & 2.66 & .855 & .000 & 2.78 & 2.57 & .074 & .015 & 2.97 & 2.52 & 2.80 & 2.54 & .061 & .035 \\
\hline Item 14 & 3.30 & 3.10 & 3.44 & .051 & .018 & 3.43 & 3.17 & .504 & .002 & 2.69 & 3.06 & 3.20 & 3.93 & .000 & .091 \\
\hline Item 17 & 2.73 & 2.54 & 2.87 & .081 & .015 & 2.69 & 2.77 & .800 & .000 & 2.80 & 2.76 & 2.85 & 2.56 & .415 & .014 \\
\hline Item 28 & 3.94 & 3.93 & 3.95 & .987 & .000 & 4.02 & 3.86 & .109 & .012 & 4.17 & 3.78 & 4.05 & 3.87 & .741 & .006 \\
\hline Item 31 & 4.00 & 3.93 & 4.06 & .493 & .002 & 3.98 & 4.03 & .604 & .001 & 3.72 & 4.05 & 4.16 & 3.97 & .347 & .016 \\
\hline
\end{tabular}

Note: 1. It is easier for children than adults to learn a foreign language; 2.Some people have a special ability for learning foreign languages; 5. People from my country are good at learning foreign languages; 9. It is easier for someone who already speaks a foreign language to learn another one; 10. People who are good at mathematics or science are not good at learning foreign languages; 14 . I have a special ability for learning foreign languages; 17 . Women are better than men at learning foreign languages; 28. People who speak more than one language are very intelligent; 31 . Everyone can learn to speak a foreign language.

Table 7

Multivariate ANOVA between different groups of the participants on the subscale of the difficulty of language learning

\begin{tabular}{|c|c|c|c|c|c|c|c|c|c|c|c|c|c|c|c|}
\hline \multirow[b]{2}{*}{ Item } & \multirow[b]{2}{*}{ Total } & \multicolumn{2}{|c|}{ Gender } & \multirow[b]{2}{*}{$\mathbf{p}$} & \multicolumn{3}{|c|}{ Educational evel } & \multicolumn{8}{|c|}{ Grade } \\
\hline & & Male & Female & & $\eta^{2}$ & $\begin{array}{l}\text { Eleme- } \\
\text { ntary }\end{array}$ & $\begin{array}{l}\text { Univer- } \\
\text { sity }\end{array}$ & $\mathbf{p}$ & $\eta 2$ & 2 & 3 & 4 & 5 & $\mathbf{p}$ & $\eta 2$ \\
\hline Item 3 & 4.14 & 4.21 & 4.09 & .064 & .016 & 4.01 & 4.27 & .046 & .018 & 4.14 & 4.10 & 4.23 & 4.09 & .601 & .008 \\
\hline Item 23 & 2.92 & 2.97 & 2.88 & .699 & .001 & 3.32 & 2.50 & .000 & .105 & 3.39 & 2.78 & 2.86 & 2.86 & .060 & .034 \\
\hline Item 32 & 3.04 & 3.20 & 2.93 & .199 & .008 & 3.08 & 3.00 & .496 & .002 & 3.53 & 3.16 & 3.00 & 2.72 & .029 & .041 \\
\hline Item 33 & 2.64 & 2.58 & 2.68 & .120 & .011 & 2.89 & 2.39 & .059 & .017 & 3.28 & 2.79 & 2.25 & 2.55 & .013 & .049 \\
\hline Item 34 & 3.31 & 3.44 & 3.22 & .122 & .011 & 3.38 & 3.25 & .952 & .000 & 2.78 & 3.33 & 3.22 & 3.67 & .000 & .084 \\
\hline
\end{tabular}

Note: 3.Some languages are easier to learn than others; 23. It is easier to speak than understand a foreign language; 32. It is easier to read and write English than to speak and understand it; 33 . If someone spent one hour a day learning a language, how long would it take them to speak the language very well?

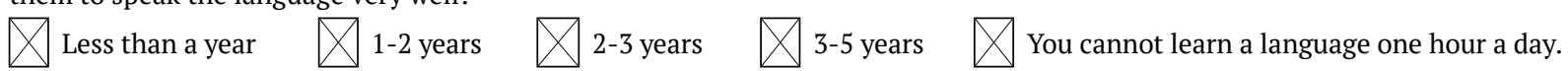

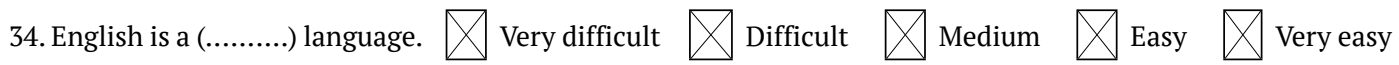


Table 8

Multivariate ANOVA between different groups of the participants on the subscale of the nature of language learning

\begin{tabular}{|c|c|c|c|c|c|c|c|c|c|c|c|c|c|c|c|}
\hline \multirow[b]{2}{*}{ Items } & \multirow[b]{2}{*}{ Total } & \multicolumn{4}{|c|}{ Gender } & \multicolumn{4}{|c|}{ Educational level } & \multicolumn{6}{|c|}{ Grade } \\
\hline & & Male & Female & $\mathbf{p}$ & $\eta 2$ & $\begin{array}{c}\text { Eleme- } \\
\text { ntary }\end{array}$ & $\begin{array}{l}\text { Univer- } \\
\text { sity }\end{array}$ & $\mathbf{p}$ & $\eta 2$ & 2 & 3 & 4 & 5 & $\mathbf{p}$ & $\eta 2$ \\
\hline Item 7 & 3.17 & 3.24 & 3.12 & .973 & .000 & 3.50 & 2.85 & .000 & .061 & 3.83 & 3.05 & 3.02 & 3.07 & .004 & .061 \\
\hline Item 11 & 4.07 & 4.15 & 4.02 & .097 & .013 & 3.85 & 4.31 & .002 & .047 & 4.14 & 4.11 & 4.11 & 3.97 & .723 & .006 \\
\hline Item 15 & 4.03 & 4.07 & 4.01 & .473 & .002 & 4.28 & 3.78 & .000 & .065 & 4.03 & 4.00 & 4.11 & 4.00 & .245 & .019 \\
\hline Item 21 & 3.57 & 3.52 & 3.61 & .052 & .018 & 3.95 & 3.19 & .000 & .123 & 3.72 & 3.66 & 3.41 & 3.57 & .155 & .024 \\
\hline Item 25 & 3.90 & 3.82 & 3.96 & .455 & .003 & 3.68 & 4.12 & .039 & .020 & 4.17 & 3.89 & 3.89 & 3.78 & .743 & .006 \\
\hline Item 26 & 3.46 & 3.47 & 3.46 & .847 & .000 & 3.75 & 3.17 & .000 & .062 & 3.67 & 3.57 & 3.33 & 3.38 & .344 & .016 \\
\hline
\end{tabular}

Note: 7. It is necessary to learn about English speaking cultures to speak English; 11. It is best to learn English in an English speaking country; 15 The most important part of learning a foreign language is learning new words; 21 . The most important part of learning a foreign language is learning grammar; 25 . Learning a foreign language is different than learning other academic subjects; 26 . The most important part of learning English is learning how to translate from my own language.

Table 9

Multivariate ANOVA between different groups of the participants on the subscale of learning and communication strategies

\begin{tabular}{|c|c|c|c|c|c|c|c|c|c|c|c|c|c|c|c|}
\hline \multirow[b]{2}{*}{ Item } & \multirow[t]{2}{*}{ Total } & \multicolumn{2}{|c|}{ Gender } & \multirow[b]{2}{*}{$\mathbf{p}$} & \multirow[b]{2}{*}{$\eta 2$} & \multicolumn{2}{|c|}{ Educational evel } & \multirow[b]{2}{*}{$\mathbf{p}$} & \multirow[b]{2}{*}{$\eta 2$} & \multicolumn{4}{|c|}{ Grade } & \multirow[b]{2}{*}{$\mathbf{p}$} & \multirow[b]{2}{*}{$\eta 2$} \\
\hline & & Male & Female & & & $\begin{array}{c}\text { Eleme- } \\
\text { ntary }\end{array}$ & $\begin{array}{l}\text { Univer- } \\
\text { sity }\end{array}$ & & & 2 & 3 & 4 & 5 & & \\
\hline Item 6 & 3.58 & 3.60 & 3.57 & .869 & .000 & 3.84 & 3.32 & .002 & .045 & 3.83 & 3.54 & 3.51 & 3.56 & .567 & .010 \\
\hline Item 8 & 2.11 & 2.03 & 2.16 & .109 & .012 & 2.22 & 1.99 & .035 & .022 & 2.42 & 2.14 & 2.09 & 1.93 & .071 & .033 \\
\hline Item 12 & 3.90 & 3.85 & 3.93 & .748 & .001 & 3.83 & 3.96 & .120 & .012 & 3.37 & 4.02 & 3.91 & 4.06 & .061 & .035 \\
\hline Item 13 & 3.69 & 3.68 & 3.69 & .976 & .000 & 3.68 & 3.69 & .338 & .004 & 3.78 & 3.62 & 3.71 & 3.68 & .835 & .004 \\
\hline Item 16 & 4.50 & 4.42 & 4.55 & .176 & .009 & 4.64 & 4.35 & .036 & .004 & 4.50 & 4.44 & 4.45 & 4.60 & .983 & .001 \\
\hline Item 19 & 2.41 & 2.39 & 2.43 & .498 & .002 & 2.31 & 2.52 & .812 & .000 & 3.11 & 2.63 & 2.33 & 1.93 & .001 & .075 \\
\hline Item 20 & 3.61 & 3.53 & 3.66 & .632 & .001 & 3.78 & 3.43 & .012 & .030 & 3.69 & 3.48 & 3.69 & 3.61 & .651 & .008 \\
\hline Item 24 & 3.72 & 3.63 & 3.79 & .867 & .000 & 3.74 & 3.70 & .931 & .000 & 3.67 & 3.64 & 3.71 & 3.83 & .707 & .007 \\
\hline
\end{tabular}

Note: 6. It is important to speak English with an excellent pronunciation; 8. You shouldn't say anything in English until you can say it correctly; 12. I enjoy practicing English with the native speakers of English I meet; 13. It's OK to guess if you don't know a word in English; 16. It is important to repeat and practice a lot; 19. I feel shy speaking English with other people; 20. If beginning students are allowed to make mistakes in English, it will be difficult for them to speak correctly later on; 24. It's important to practice with audio materials.

Table 10

Multivariate ANOVA between different groups of the participants on the subscale of motivation and expectations

\begin{tabular}{|c|c|c|c|c|c|c|c|c|c|c|c|c|c|c|c|}
\hline \multirow[b]{2}{*}{ Item } & \multirow[t]{2}{*}{ Total } & \multicolumn{2}{|c|}{ Gender } & \multirow[b]{2}{*}{$\mathbf{p}$} & \multirow[b]{2}{*}{$\eta 2$} & \multicolumn{2}{|c|}{ Educational evel } & \multicolumn{8}{|c|}{ Grade } \\
\hline & & Male & Female & & & $\begin{array}{c}\text { Eleme- } \\
\text { ntary }\end{array}$ & $\begin{array}{c}\text { Univer- } \\
\text { sity }\end{array}$ & $\mathbf{p}$ & $\eta 2$ & 2 & 3 & 4 & 5 & $\mathbf{p}$ & $\eta 2$ \\
\hline Item 4 & 4.13 & 4.11 & 4.15 & .955 & .000 & 4.07 & 4.19 & .178 & .009 & 3.42 & 3.98 & 4.26 & 4.51 & .000 & .093 \\
\hline Item 18 & 3.68 & 3.22 & 3.84 & .106 & .012 & 3.70 & 3.67 & .303 & .005 & 3.37 & 3.56 & 3.91 & 3.75 & .011 & .051 \\
\hline Item 22 & 3.79 & 3.86 & 3.74 & .571 & .002 & 4.23 & 3.35 & .000 & .113 & 4.00 & 3.44 & 3.86 & 4.00 & .135 & .026 \\
\hline Item 27 & 4.33 & 4.30 & 4.35 & .494 & .002 & 4.36 & 4.30 & .467 & .003 & 4.14 & 4.40 & 4.30 & 4.40 & .815 & .004 \\
\hline Item 29 & 4.55 & 4.54 & 4.55 & .636 & .001 & 4.56 & 4.54 & .884 & .000 & 4.44 & 4.44 & 4.57 & 4.68 & .292 & .018 \\
\hline Item 30 & 4.22 & 4.09 & 4.30 & .195 & .008 & 4.22 & 4.21 & .835 & .000 & 4.00 & 3.95 & 4.28 & 4.51 & .045 & .038 \\
\hline
\end{tabular}

Note: 4.I believe that I will learn to speak English better; 18 . People in my country feel that it is important to speak English; 22 . I would like to learn English so that I can get to know Americans/British better; 27. If I learn to speak English very well, I will have better job opportunities; 29. I want to learn to speak English very well; 30. I would like to have English speaking friends. 


\section{Discussion}

The statistical analysis displayed in the previous section partially confirmed both hypotheses. The findings revealing that gender had no significant effect on the overall beliefs measured by means of the BALLI confirmed the results reported by Bernart and Lloyd (2007), Lee (2014), and Tercanioglu (2005), but contradicted those presented in Fujiwara (2014) and Bernat (2006). Even when the female and male students' stances were analyzed separately for the five areas of beliefs, no significant differences were observed. Thus, it appears that gender as a sole factor does not play a key role in modifying learners' beliefs in this case, as both the male and female participants shared more or less the same attitudes towards the English learning experience. Still, some minor differences were noticed; the female participants reported slightly higher motivation, similarly to the female participants in the Bacon and Finnemann's study (1992), tended to enjoy practicing more, and think that those who know more than one language are intelligent, as was held by the female participants in the study by Bernat and Lloyd (2007), and they also expressed greater readiness to speak with target language speakers, as found in the studies by Siebert (2003), Bacon and Finnemann (1992), and Kunt (1997). Even though these general tendencies seem to be evident across different research, some contrary findings were reported here. For instance, Siebert (2003) indicated that the male students believed more in their and their country people's language learning abilities, claimed they needed less time to learn English, and more strongly advocated correct pronunciation and grammar. While the present study results are in agreement with the majority of these findings, our female students emphasized the importance of grammar as well as the language learning abilities of the people from their country more than their male counterparts. Thus, although a marked similarity in the beliefs of students of varied cultural background seems to exist, some stances tend to be culture-specific.

Second, contrary to some earlier findings (Fujiwara, 2014; Mori, 1999; Park, 1995; Samimy \& Lee, 1997), this study did not reveal any significant effect of achievement in terms of English grade level on the overall BALLI. However, when the stances were compared between the groups on specific areas of beliefs, they significantly differed on the area of motivation and expectations. Thus, those more successful students were more confident in their and their country people's capacity to learn English, as also indicated in Fujiwara's (2014) study. At the same time, the majority of those with better grades were also less shy and more skeptic about the importance of grammar, translation, and perfect pronunciation. Similarly, aligning with the results reported by Park (1995) and Samimy and Lee (1997), those who were more successful tended to have more confidence in their abilities and expressed a stronger willingness to communicate in English. On the contrary, the less successful students were more convinced that a prerequisite for successful oral communication in English was a deep knowledge of the target culture. These findings clearly indicate that the priority of successful language learners - the ones more confident, open, and communication-oriented - is effective communication rather than perfect grammar or pronunciation. Naturally, thanks to this attitude, the experience of language acquisition appears easier and more enjoyable.

Nevertheless, it seems that out of the three factors, the strongest impact was exerted by the educational level, i.e. the age of the participants. Although Fujiwara (1999) found no difference between age groups, it should be emphasized that the participants were 17 and 18-year old students in group 1,19-year olds in group 2, and $20+$ in group 3. The age difference between the current study's groups was much greater, so the stances of the groups significantly diverged in terms of the overall BALLI as well as the area of the nature of language learning, which might be attributed to the length and wealth of experiences acquiring different languages. Thus, the elementary school students highlighted the significance of learning about the target language culture, of grammar, correct pronunciation, learning new words, and translation, whereas the university students accentuated communication with the target language speakers as crucial for successful language acquisition. Interestingly, the older students believed more that children are better language learners than adults. Although there was no significant difference when it came to the statement related to the difficulty of English language learning, the results support the conclusion by Mantle-Bromley's study (1995) that younger students in their study tended to underestimate the difficulty of language learning in comparison with the university-level students in the studies by Horwitz (1988) and Kern (1995). Therefore, experience evidently modifies some of the attitudes, as it appears that students start appreciating acquisition through communication rather than explicit instruction after years of language learning. They also tend to become less shy when speaking and more readily accept errors as natural in the process of language learning. Their aims of language learning also seem to change, as they begin to see more value in learning English as one of the main assets in their prospective academic and professional pursuits rather than merely a cultural exchange or friendship with native speakers of the language. 
After analyzing the differences in the stances related to the specific factors separately, their combined effect was investigated. The interaction effect of grades and gender, grades, and gender and educational level was insignificant on the overall BALLI as well as the separate areas of beliefs. Conversely, educational level and grades, although having an insignificant effect on the BALLI, proved to significantly impact the area of the nature of language learning. Thus, for example, the more successful the university students were, the less they believed in the value of learning English in the English-speaking country and in the importance of learning about the target language grammar, while either the contrary or no significant difference between the scores was noticed among the elementary school students. Similarly, educational level and gender were found to interact significantly in the effect on the BALLI and three areas: the nature of language learning, motivation and expectations, and learning and communication strategies. Thus, the beliefs common to one group of the participants seem to change over time. Therefore, while the male elementary school students in the initial learning stages tended to demonstrate stronger support for the importance of learning new words, guessing, translation, correct pronunciation, and error correction than their female classmates, the opposite was shown among university students. The elementary school male students also reported being more shy when speaking English, less ready to practice it with native speakers, and expressing a stronger wish to speak English well and learn it better for the sake of understanding the native culture as well as for their professional success, unlike the male university students. This clearly confirms that such epistemological beliefs are dynamic and moldable under the influence of new experiences (Ellis, 2003; Kern, 1995; Mercer, 2011; Zhong, 2015). However, this study also indicates that the impact of one factor becomes more evident when investigated in the interplay with other relevant factors. Some attitudes adopted by the majority of male elementary school students tend to get firmer support among female students after some time, even though both groups acquire the target language in similar learning conditions. Similarly, more successful students at an elementary school level do not necessarily report the same approval for some statements as those who are more successful at the university level. Therefore, any analysis of the relation or the impact of varied factors on the LLBs should be focused on their interplay to provide greater insight into the issue.

\section{Conclusion}

The present study attempted to analyze foreign language students' beliefs about their English language learning and to explore how three factors - gender, educational level, and grades, separately and interacting with one another - influenced their stances on foreign language aptitude, the difficulty and nature of language learning, learning and communication strategies, and motivation and expectations.

The results showed an insignificant effect of grades and gender and a significant effect of educational level on the overall beliefs expressed by the BALLI, while only the interaction effect of educational level and gender on the statements proved significant. On the other hand, when the impact of the factors was evaluated separately for the five areas, the effect of grades was significant on the stances related to the area of motivation and expectations, whereas educational level was found to significantly affect the area of the nature of language learning. Here, the interaction effect of grades and educational level was significant on the area of the nature of language learning, while educational level in the interaction with gender also significantly affected three areas, namely the nature of language learning, motivation and expectations, as well as learning and communication strategies.

In a broader interpretation, the study showed that, rather than understanding language learning beliefs as being shaped by isolated individual traits, it seems more beneficial to observe them as a fluid outcome of a combination of factors. Here, it was demonstrated that educational level plays an important role not only as an isolated factor but also in combination with, first of all, achievement, when shaping the understanding of the nature of language learning, and secondly, gender, in their influence on the entirety of the convictions as well as some specific areas.

Thus, considering the finding that educational level, i.e. age, carries a significant effect on beliefs, the study indicates that, first of all, beliefs are modifiable, and, secondly, that they change in synchronization with relevant experiences. Such a finding carries significant pedagogical implications mainly because it can serve as a sound basis for educators to intentionally work on their students' beliefs, with a specific method and direction in 
mind. In terms of the method, educators should provide students with the opportunity to experience rather than hear about the ways in which their language learning can be more successful. Regarding the direction, teachers should work on remodeling their students' beliefs so that they mirror the ones held by more successful students.

However, the strength of the notion that educational level plays a crucial role here was limited by the fact that this study's participants did not include a portion of high school students, which would have allowed for clearer indications of the gradual time-bound change of beliefs. Therefore, further research on this issue should include a larger and more diverse sample study. Moreover, as is naturally the case with quantitative instruments, another limitation of the study was the potentially simplified illustration of their beliefs due to statements that did not necessarily reflect the complexities beliefs usually possess. Therefore, another study with an additional instrument requiring participants to provide qualitative responses on both their beliefs and the modifications of those beliefs could paint a more layered and thus clearer picture of the matter. Along similar lines, it could be argued that this particular issue should be increasingly studied as a longitudinal study in which the gradual modifications could be researched not in the form of assumptions but rather tangible data on learners' transformations and thus naturally provide firmer inferences.

Finally, it is important to emphasize here that epistemological beliefs in general, and language learning beliefs in particular, are to be observed and researched continuously and variously in order to, first, inform educators that students' learning is grounded in a set of beliefs that navigate their experience and thus lead to positive or negative outcomes, and second, motivate them to bring awareness to and properly manage such convictions.

\section{Conflict of Interest}

The authors declare that they have no conflict of interest.

\section{References}

Abdolahzadeh, E. \& Nia, M. R. (2014). Language learning beliefs of Iranian learners: Examining the role of English language proficiency. Procedia-Social and Behavioral Sciences, 98, 22-28. https://doi.org/10.1016/j. sbspro.2014.03.384.

Abraham, R., \& Vann, R. (1987). Strategies of two language learners: a case study. In A. Wenden \& J. Rubin (Eds.), Learner strategies in language learning (pp. 85-102). Englewood Cliffs, NY: Prentice/Hall International.

Amuzie, G. L., \& Winke, P. (2009). Changes in language learning beliefs as a result of study abroad. System, 37(3), 366-379. https://doi.org/10.1016/j.system.2009.02.011.

Ariogul, S., Unal, D. C., \& Onursal, I. (2009). Foreign language learners' beliefs about language learning: A study on Turkish university students. Procedia-Social and Behavioral Sciences, 1(1), 1500-1506. https://doi. org/10.1016/j.sbspro.2009.01.265.

Azar, F. K., \& Saeidi, M. (2013). The relationship between Iranian EFL learners' beliefs about language learning and their use of learning strategies. English Language Teaching, 6(11), 167-174. https://doi.org/10.5539/elt. v6n11p167.

Bacon, S. M., \& Finnemann, M. D. (1992). Sex differences in self-reported beliefs about foreign-language learning and authentic oral and written input. Language Learning, 42(4), 471-495.

Barcelos, A. M. F. (2000). Understanding teachers' and students' language learning beliefs in experience: A Deweyan approach (Unpublished doctoral dissertation). University of Alabama, Tuscaloosa, Alabama.

Bećirović S., Brdarević, Č. A., \& Sinanović, J. (2017). The use of metacognitive reading strategies among students at International Burch University: A case study. European Journal of Contemporary Education, 6, 645-655. https://doi.org/10.13187/ejced.2017.4.645.

Benson, P. (2001). Autonomy in language learning. Harlow, UK: Longman.

Benson, P., \& Lor, W. (1999). Conceptions of language and language learning. System, 27(4), 459-472.

Benson, P., \& Nunan, D. (Eds.). (2004). Learners' stories: Difference and diversity in language learning. Cambridge, UK: Cambridge University Press.

Bernat, E. (2004). Investigating Vietnamese ESL learners' beliefs about language learning. The English Australia 
Journal, 21(2), 40-54.

Bernat, E. (2006). Assessing EAP learners' beliefs about language learning in the Australian context. Asian EFL Journal, 8(2), 202-227.

Bernat, E., \& Gvozdenko, I. (2005). Beliefs about language learning: Current knowledge, pedagogical implications, and new research directions. Teaching English as a Second or Foreign Language, 9(1), 1-21.

Bernat, E., \& Lloyd, R. (2007). Exploring the gender effect on EFL learners' beliefs about language learning. Australian Journal of Educational \& Developmental Psychology, 7, 79-91.

Brdarević, Č. A., \& Asotić, M. (2017). The influence of social context, grade level and gender on the use of language learning strategies in primary schools. Imperial Journal of Interdisciplinary Research, 3(12), 7-14.

Brdarević, Č. A., Bećirović, S., \& Bureković, M. (2018). The use of imaginative conditional clauses by Bosnian university-level English-majoring students. Journal of Linguistic and Intercultural Education, 11(2), 25-40. https://doi.org/10.29302/jolie.2018.11.2.2.

Castellotti, V., \& Moore, D. (2002). Social representations of languages and teaching. In Language policy division, directorate of schools, out-of-school and higher education (pp. 10 - 14). Strasbourg, France: Council of Europe.

Chapelle, C., \& Green, P. (1992). Field independence/dependence in second-language acquisition research. Language learning, 42(1), 47-83.

Chaudron, C. (2003). Learner strategies (Review paper commissioned by the Diagnostic Assessment Procedure Project). Honolulu, HI: Centre for Advanced Language Studies, University of Hawaii.

Clark, C. M. (1988). Asking the right questions about teacher preparation: Contributions of research on teacher thinking. Educational researcher, 17(2), 5-12.

Csizér, K., \& Lukács, G. (2010). The comparative analysis of motivation, attitudes and selves: The case of English and German in Hungary. System, 38(1), 1-13. https://doi.org/10.1016/j.system.2009.12.001.

Csizér, K., \& Dörnyei, Z. (2005). The internal structure of language learning motivation and its relationship with language choice and learning effort. The Modern Language Journal, 89(1), 19-36. https://doi.org/10.1111/ j.0026-7902.2005.00263.x.

Delić, H., Bećirović, S., \& Brdarević, Č. A. (2018). Effects of grade level and gender on foreign language learning process in Bosnian high schools. International Journal of Educational Policy Research and Review, 5(6), 83-89. https://doi.org/10.15739/IJEPRR.18.010.

Dewaele, J. M., \& Furnham, A. (2000). Personality and speech production: A pilot study of second language learners. Personality and Individual Differences, 28(2), 355-365.https://doi.org/10.1016/S0191-8869(99)001063.

Diab, R. L. (2006). University students' beliefs about learning English and French in Lebanon. System, 34(1), 8096. https://doi.org/10.1016/j.system.2005.06.014.

Dornyei, Z. (2005). The psychology of the language learner: Individual differences in second language acquisition. Mahwah, NJ: Lawrence Erlbaum.

Dörnyei, Z., \& Ushioda, E. (Eds.). (2009). Motivation, language identity and the L2 self. Bristol, UK: Multilingual Matters.

Dweck, C. S., \& Leggett, E. L. (1988). A social-cognitive approach to motivation and personality. Psychological Review, 95(2), 256-273.

Ehrman, M. (1990). Owls and doves: Cognition, personality, and learning success. In Linguistics, language teaching, and language acquisition: The interdependence of theory, practice, and research (pp. 413-437). Washington, DC: Georgetown University Press.

Ehrman, M., \& Leaver, B. L. (2003). Cognitive styles in the service of language learning. System, 31(3), 393-415. https://doi.org/10.1016/S0346-251X(03)00050-2.

Ehrman, M. E., \& Oxford, R. L. (1995). Cognition plus: Correlates of language learning success. The Modern Language Journal, 79(1), 67-89.

Ellis, R. (1994). The study of second language acquisition. Oxford, UK: Oxford University.

Fillmore, L. W. (1979). Individual differences in second language acquisition. In C. J. Fillmore, D. Kempler and W. S. Y. Wang (Eds.). Individual differences in language ability and language behavior (pp. 203-228). Massachusetts, Mass: Academic Press.

Flavell, J. H. (1987). Speculations about the nature and development of metacognition. In F. E. Weinert \& R. Kluwe (Eds.), Metacognition, motivation and understanding (pp. 21-29). Hillsdale, NJ: Lawrence Erlbaum.

Fujiwara, T. (2014). Language learning beliefs of Thai EFL university students: Variations related to achievement levels and subject majors. Electronic Journal of Foreign Language Teaching, 11(2), 300-311.

Gardner, R. C., \& MacIntyre, P. D. (1992). A student's contributions to second language learning. Part I: Cognitive variables. Language Teaching, 25(4), 211-220. 
Gardner, R. C., \& MacIntyre, P.D. (1993). A student's contributions to second-language learning. Part II: Affective variables. Language teaching, 25(1), 1-11.

Gardner, R. C., Masgoret, A. M., \& Tremblay, P. F. (1999). Home background characteristics and second language learning. Journal of Language and Social Psychology, 18(4), 419-437.

Gardner, R. C., Tremblay, P. F., \& Masgoret, A. M. (1997). Towards a full model of second language learning: An empirical investigation.The Modern Language Journal, 81(3), 344-362.

Ghavamnia, M., Kassaian, Z., \& Dabaghi, A. (2011). The relationship between language learning strategies, language learning beliefs, motivation, and proficiency: A study of EFL learners in Iran. Journal of Language Teaching \& Research, 2(5), 1156-1161. https://doi.org/10.4304/jltr.2.5.1156-1161.

Goh, C. (1997). Metacognitive awareness and second language listeners. ELT Journal, 51(4), 361-369. https://doi. org/10.1093/elt/51.4.361.

Habibić, A., \& Dubravac, V. (2016). Grammar acquisition in Bosnian EFL classrooms. Pismo, XIV, 127-140.

Harri-Augstein, E. S., \& Thomas, L. F. (1983). Developing self-organized learners: A reflective technology. New Directions for Adult and Continuing Education, 19, 39-48. https://doi.org/10.1002/ace.36719831906.

Hong, K. (2006). Beliefs about language learning and language learning strategy use in an EFL context: A comparison study of monolingual Korean and bilingual Korean-Chinese university students (Unpublished doctoral dissertation). University of North Texas, Denton, Texas.

Horwitz, E. K. (1987). Surveying student beliefs about language learning. In A. Wenden \& J. Rubin (Eds.), Learner strategies in language learning (pp. 110-129). London, UK: Prentice Hall.

Horwitz, E. K. (1988). The beliefs about language learning of beginning university foreign language students. The modern language journal, 72(3), 283-294.

Horwitz, E. K. (1999). Cultural and situational influences on foreign language learners' beliefs about language learning: A review of BALLI studies. System, 27(4), 557-576.

Horwitz, E. K., Horwitz, M. B., \& Cope, J. (1986). Foreign language classroom anxiety. The Modern Language Journal, 70(2), 125-132.

Kalaja, P., \& Barcelos, A. M. F. (2003). Conclusion: Exploring possibilities for future research on beliefs about SLA. In P. Kalaja \& A. M. F. Barcelos (Eds.), Beliefs about SLA (pp. 231-238). Dordrecht, Netherlands: Springer.

Kern, R. G. (1995). Students' and teachers' beliefs about language learning. Foreign Language Annals, 28(1), 7192. https://doi.org/10.1111/j.1944-9720.1995.tb00770.x.

Kim, H. J. (2001). Language learning strategies, learning styles, and beliefs about language learning of Korean university students. Journal of Pan-Pacific Association of Applied Linguistics, 5(1), 31-46.

Kim-Yoon, H. (2000). Learner beliefs about language learning, motivation and their relationship: A study of EFL learners in Korea (Unpublished doctoral dissertation). The University of Texas at Austin, Austin, Texas.

Khodadady, E. (2009). The beliefs about language learning inventory: Factorial validity, formal education and the academic achievement of Iranian students majoring in English. Iranian Journal of Applied Linguistics, 12(1), 116-165.

Kovačević, E. (2017). The relationship between language learning beliefs and syntactic complexity. Jezici i Kulture u Vremenu i Prostoru, 6, 455-464.

Kovačević, E., \& Akbarov, A. (2015). Language learning beliefs and strategies: A Bosnian EFL Case. Epiphany: Journal of Transdisciplinary Studies, 8(3), 74-87.

Kovačević, F., Brdarević, Č. A., \& Bećirović, S. (2018). Opportunities and challenges facing Bosnian high-school EFL learners. European Researcher. Series A, 9(4), 298-306. https://doi.org/10.13187/er.2018.4.298.

Kunt, N. (1997). Anxiety and beliefs about language learning: A study of Turkish-speaking university students learning English in North Cyprus (Unpublished doctoral dissertation). University of Texas at Austin, Austin, Texas.

Kuntz, P. S. (1997). Beliefs about language learning held by students and their teacher: A pilot study (ERIC Document Reproduction Service No. ED407853). Retrieved from: https://files.eric.ed.gov/fulltext/ED407853.pdf.

Lee, S. (2014). An examination of language learning beliefs and language learning strategy use in adult ESL learners in a higher educational setting (Unpublished doctoral dissertation). Auburn University, Alabama, USA.

MacIntyre, P. D., \& Gardner, R. C. (1994). The subtle effects of language anxiety on cognitive processing in the second language. Language learning, 44(2), 283-305.

Mantle-Bromley, C. (1995). Positive attitudes and realistic beliefs: Links to proficiency. The Modern Language Journal, 79(3), 372-386.

Mercer, S. (2011). The beliefs of two expert EFL learners. Language Learning Journal, 29(1), 57-74. https://doi.org/ 10.1080/09571736.2010.521571.

Meshkat, M., \& Saeb, F., 2014. High-school students' beliefs about learning English and Arabic. International Journal of Applied Linguistics and English Literature, 3(3), 211-216. https://doi.org/10.7575/aiac. 
ijalel.v.3n.3p.211.

Moody, R. (1988). Personality preferences and foreign language learning. The Modern Language Journal, 72(4), 389-401.

Mori, Y. (1999). Epistemological beliefs and language learning beliefs: What do language learners believe about their learning? Language learning, 49(3), 377-415.

Naiman, N., Frohlich, M., Stern, H. H., \& Todesco, A. (1978). The good language learner (Research in Education Series No. 7). Toronto, Canada: Ontario Institute for Studies in Education.

Nikitina,L., \& Furuoka,F. (2007). Beliefs about language learning: A comparison between novice and intermediate level students learning Russian at a Malaysian university. The Linguistics Journal, 2(1), 7-27.

Okogbaa, V. (2017). Preparing the teacher to meet the challenges of a changing world. Journal of Education and Practice, 8(5), 81-86. Retrieved from: https://files.eric.ed.gov/fulltext/EJ1132965.pdf.

Omaggio, A. C. (1978). Successful language learners: What do we know about them. ERIC/CLL News Bulletin, 5, $2-3$.

Oxford, R. (1990). Language learning strategies: What every teacher should know. Boston, MA: Heinle \& Heinle.

Oxford, R. (1992). Who are our students? A synthesis of foreign and second language research on individual differences with implications for instructional practice. TESL Canada Journal, 9(2), 30-49.

$\mathrm{Oz}, \mathrm{H}$. (2007). Understanding metacognitive knowledge of Turkish EFL students in secondary education. Online Submission, 1(2), 53-83.

Ozturk, I., \& Turkyilmaz, U. (2014). The beliefs of Bosnian EFL learners about language learning. European Academic Research, 3(2), 4139-4156.

Park, G. (1995). Language learning strategies and beliefs about language learning of university students learning English in Korea (Unpublished doctoral dissertation). University of Texas at Austin, Austin, Texas.

Peacock, M. (1999). Beliefs about language learning and their relationship to proficiency. International Journal of Applied Linguistics, 9(2), 247-263.

Poza, M. I. C. (2013). The beliefs of African American students about foreign language learning. North East Conference on the Teaching of Foreign Languages Review, 73, 61-78.

Ren, H., \& Bai, Y. (2016). A study of the relationship between learning belief and English achievement of Chinese English major college students. Journal of Education and Practice, 7(14), 99-103.

Richardson, V. (1996). The role of attitudes and beliefs in learning to teach. Handbook of Research on Teacher Education, 2, 102-119.

Rieger, B. (2009). Hungarian university students' beliefs about language learning: A questionnaire study. Working Papers in Languageedagogy, 3, 97-113.

Rizvić, E., Bećirović, S. (2017). Willingness to communicate in English as a foreign language in BosnianHerzegovinian EFL context. European Researcher, 8(3), 224-235. https://doi.org/10.13187/er.2017.3.224.

Ryan, M. P. (1984). Monitoring text comprehension: Individual differences in epistemological standards. Journal of Educational Psychology, 76(2), 248-258.

Samimy, K. K., \& Lee, Y. A. (1997). Beliefs about language learning: Perspectives of first-year Chinese learners and their instructors. Journal-Chinese Language Teachers Association, 32, 40-60.

Schoenfeld, A. H. (1985). Mathematical problem solving. New York, NY: Academic Press.

Schommer, M. (1990). Effects of beliefs about the nature of knowledge on comprehension. ournal of Educational Psychology, 82(3), 498-504.

Schommer, M. (1993). Comparisons of beliefs about the nature of knowledge and learning among postsecondary students. Research in Higher Education, 34(3), 355-370.

Siebert, L. L. (2003). Student and teacher beliefs about language learning. Ortesol (Oregon Teachers of English to Speakers of Other Languages) Journal, 21, 7-39.

$\mathrm{Su}, \mathrm{D}$. (1995). A study of English learning strategies and styles of Chinese university students in relation to their cultural beliefs and beliefs about learning English (Unpublished doctoral dissertation). University of Georgia, Athens, Georgia.

Tanaka, K., \& Ellis, R. (2003). Study abroad, language proficiency, and learner beliefs about language learning. JALT journal, 25(1), 63-85.

Tankosić, A., \& Dubravac, V. (2016). The assessment of Bosnian EFL learners' knowledge by two different measures: Test and writing assignment. Explorations in English Language and Linguistics, 4(1), 41-57. https:// doi.org/10.1515/exell-2017-0006.

Tercanlioglu, L. (2005). Pre-service EFL teachers' beliefs about foreign language learning and how they relate to gender. Electronic Journal of Research in Educational Psychology, 3(1), 145-162. Retrieved from: http:// investigacion-psicopedagogica.org/revista/articulos/5/english/Art_5_58.pdf. 
Verhoeven, L., \& Vermeer, A. (2002). Communicative competence and personality dimensions in first and second language learners. Applied Psycholinguistics, 23(3), 361-374. https://doi.org/10.1017/S014271640200303X.

Wenden, A. L. (1986a). Helping language learners think about learning. ELT Journal, 40(1), 3-12.

Wenden, A. L. (1986b). What do second-language learners know about their language learning? A Second look at retrospective accounts. Applied linguistics, 7(2), 186-205.

Wenden, A. (1991). Learner strategies for learner autonomy. New York, NY: Prentice Hall.

Wenden, A. L. (1998). Metacognitive knowledge and language learning1. Applied Linguistics, 19(4), 515-537.

Wenden, A. L. (1999). An introduction to metacognitive knowledge and beliefs in language learning: Beyond the basics. System, 27(4), 435-441.

Wenden, A. L. (2001). Metacognitive knowledge in SLA: The neglected variable. In M. P. Breen (Ed.), Learner contributions to language learning: New directions in research (pp. 44-64). Harlow, UK: Longman.

White, C. J. (1999a). Expectations and emergent beliefs of self-instructed language learners. System, 27(4), 443457.

White, C. J. (1999b). The metacognitive knowledge of distance learners. Open Learning: The Journal of Open, Distance and e-Learning, 14(3), 37-46.

Yang, N.D. (1992). Second language learners' beliefs about language learning and their use of learning strategies: A study of college students of English in Taiwan. Dissertation Abstracts International, 53(8), 2722A (UMI No.9225771).

Yang, N. D. (1999). The relationship between EFL learners' beliefs and learning strategy use. System, 27(4), 515535.

Zhang, X., \& Cui, G. (2010). Learning beliefs of distance foreign language learners in China: A survey study. System, 28(1), 30-40. https://doi.org/10.1016/j.system.2009.12.003.

Zhong, Q. (2012). The beliefs and learner strategy use of low-proficiency Chinese learners and their impact on learning English in a New Zealand context (Unpublished doctoral dissertation). The University of Auckland, Auckland, New Zealand.

Zhong, Q. M. (2014). Understanding changes in Chinese immigrant language learners' beliefs in New Zealand. The Electronic Journal for English as a Second Language, 17(4), 1-20. Retrieved from: http://www.tesl-ej.org/ pdf/ej68/a3.pdf.

Zhong, Q. M. (2015). The nature of language learners' beliefs: A half-told story. International Journal of English Studies, 15(2), 41-60. https://doi.org/10.6018/ijes/2015/2/220061. 